Original Article

\title{
Mosquitocidal activities of Chenopodium botrys whole plant n-hexane extract against Culex quinquefasciatus
}

\author{
Atividades mosquitocidas do extrato de n-hexano de planta inteira de Chenopodium \\ botrys contra Culex quinquefasciatus
}

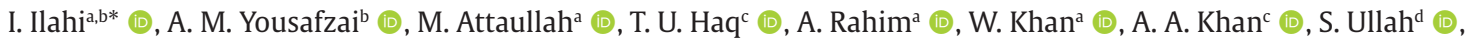

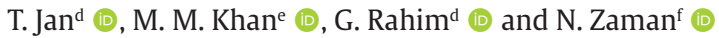 \\ aUniversity of Malakand, Department of Zoology, Chakdara, Dir Lower, Khyber Pakhtunkhwa, Pakistan \\ 'Islamia College Peshawar, Department of Zoology, Peshawar, Khyber Pakhtunkhwa, Pakistan \\ 'University of Malakand, Department of Biotechnology, Chakdara, Dir Lower, Khyber Pakhtunkhwa, Pakistan \\ dUniversity of Malakand, Department of Botany, Chakdara, Dir Lower, Khyber Pakhtunkhwa, Pakistan \\ 'The University of Haripur, Department of Microbiology, Haripur, Khyber Pakhtunkhwa, Pakistan \\ fUniversity of Swat, Centre for Biotechnology and Microbiology, Swat, Khyber Pakhtunkhwa, Pakistan
}

\begin{abstract}
This research aimed to investigate various mosquitocidal activities of Chenopodium botrys whole- plant n-hexane extract against Culex quinquefasciatus. The extract showed remarkable larvicidal, pupicidal, adulticidal, oviposition deterrent and adult emergence inhibitory activities against $C x$. quinquefasciatus. During the larvicidal and pupicidal activities, the 24 -hour lethal concentration $\left(\mathrm{LC}_{50}\right)$ of extract against $2^{\text {nd }}$ instar larvae, $4^{\text {th }}$ instar larvae and pupae were 324.6, 495.6 and 950.8 ppm, respectively. During the CDC (Centers for Disease Control and Prevention) bottle bioassay for adulticidal activity, the median knockdown times $\left(\mathrm{KDT}_{50}\right)$ at $1.25 \%$ concentration was 123.4 minutes. During the filter paper impregnation bioassay for adulticidal activity, the $\mathrm{KDT}_{50}$ value at $0.138 \mathrm{mg} / \mathrm{cm}^{2}$ concentration was 48.6 minutes. The extract was fractionated into 14 fractions through silica gel column chromatography which were then combined into six fractions on the basis of similar retention factor ( $\mathrm{Rf}$ ) value. These fractions were screened for adulticidal activity by applying CDC bottle bioassay. The fraction obtained through 60:40 to 50:50\% $\mathrm{n}$-hexanes-chloroform mobile phase with $0.5 \mathrm{Rf}$ value showed $100 \%$ adulticidal activity at $0.2 \%$ concentration. During oviposition deterrent activity, the highest concentration $(1000 \mathrm{ppm})$ showed $71.3 \pm 4.4 \%$ effective repellence and $0.6 \pm 0.1$ oviposition activity index. During adult emergence inhibition activity, the median emergence inhibition $\left(\mathrm{EI}_{50}\right)$ value was $312.3 \mathrm{ppm}$. From the outcome of the present investigation, it is concluded that the n-hexane extract of $C$. botrys whole- plant possesses strong larvicidal, pupicidal, adulticidal, oviposition deterrent and adult emergence inhibitory activities against $C x$. quinquefasciatus.
\end{abstract}

Keywords: adulticidal, column chromatography, column fractions, larvicidal, pupicidal.

\begin{abstract}
Resumo
Esta pesquisa teve como objetivo investigar várias atividades mosquitocidas do extrato n-hexano de planta inteira de Chenopodium botrys contra Culex quinquefasciatus. $\mathrm{O}$ extrato mostrou atividades larvicida, pupicida, adulticida, dissuasora de oviposição e inibidora da emergência de adultos contra a $C x$. quinquefasciatus. Durante as atividades larvicida e pupicida, a concentração letal de 24 horas (CL50) do extrato contra larvas de $2^{\circ}$ estádio, larvas de $4^{0}$ estádio e pupa foi de 324,6, 495,6 e 950,8 ppm, respectivamente. Durante o bioensaio com frasco do CDC (Centros para Controle e Prevenção de Doenças) para adulticida, o tempo médio de desativação (KDT50) na concentração de 1,25\% foi de 123,4 minutos. Durante o bioensaio de impregnação com papel de filtro para a atividade adulticida do extrato, o valor KDT50 na concentração de $0,138 \mathrm{mg} / \mathrm{cm}^{2}$ foi de 48,6 minutos. 0 extrato foi fracionado em 14 frações através de cromatografia em coluna de gel de sílica que foram então combinadas em seis frações com base em um valor de fator de retenção (Rf) semelhante. Essas frações foram selecionadas quanto à atividade adulticida por meio da aplicação do bioensaio com garrafa do CDC. A fração obtida através da fase móvel de n-hexanos-clorofórmio 60:40\% a 50:50\% com valor de 0,5 Rf apresentou atividade adulticida de $100 \%$ na concentração de 0,2\%. Durante a atividade de dissuasão da oviposição, a maior concentração de extrato (1000 ppm) apresentou repelência efetiva de $71,3 \pm 4,4 \%$ e índice de atividade de oviposição de 0,6 $\pm 0,1$. Durante a atividade de inibição da emergência de adultos, o valor médio de inibição da emergência (EI50) foi de $312,3 \mathrm{ppm}$. A partir do resultado da presente investigação, conclui-se que o extrato de n-hexano da planta inteira de $C$. botrys possui fortes atividades larvicida, pupicida, adulticida, dissuasora da oviposição e inibidora da emergência de adultos contra a $C x$. quinquefasciatus.
\end{abstract}

Palavras-chave: adulticida, cromatografia em coluna, frações de coluna, larvicida, pupicida.

*e-mail: ikramilahi@uom.edu.pk

Received: July 11, 2020 - Accepted: December 21, 2020

This is an Open Access article distributed under the terms of the Creative Commons Attribution License, which permits unrestricted use, distribution, and reproduction in any medium, provided the original work is properly cited. 


\section{Introduction}

Synthetic chemical insecticides play role in pest control. They belong to the carbamate, organophosphate, organochlorine, pyrethroid, and neonicotinoid pesticide (Gullan and Cranston, 2014). Organochlorines were first introduced in the market during 1940s which were then succeeded by organophosphates and carbamates, pyrethroids and most recently by neonicotinoids in 1990s (Casida and Durkin, 2013).

Mosquitoes are small blood sucking insects and transmit several diseases in humans such as filariasis, dengue, yellow fever and malaria (Farajollahi et al., 2011). Culex quinquefasciatus (Diptera: Culicidae) is the most wide spread mosquito in tropical and subtropical regions and breeds in wide range of stagnant water bodies such as cemented drains, ditches, pools, rice fields, river margins, marshes, wells and ponds (Kramer et al., 2008; Andreadis, 2012; Ilahi and Suleman, 2013). Its irritating biting creates nuisance and is responsible for transmitting the pathogen of lymphatic filariasis (elephantiasis, Wuchereria bancrofti) (Ramaiah et al., 2003). Millions of people suffer from filariasis in different regions of the world (Simonsen, 2009). Few cases of tropical pulmonary eosinophilia in Pakistan have also been reported (Beg et al., 2001). Cx. quinquefasciatus is also known for transmitting malaria in birds (Glad and Crampton, 2015).

Disease transmitting mosquitoes are controlled by the application of chemical insecticides in addition to habitat reduction. Constant and frequent application of insecticides has contaminated the environment, affected the non-target organisms, harmed human health, and developed insecticide resistance in pests (Lee et al., 2001). Application of environment friendly approaches for control of insect pests is gaining attention (Ghosh et al., 2012; Benelli, 2015). Biological control is the common method and ecofriendly approach to pest control. Several living organisms such as microbes (Das et al., 2016), natural predators (Mandal et al., 2008), and plants (Ajaegbu et al., 2016) have been described for their mosquitocidal effects. It is claimed that insecticides derived from medicinal plants are safe for other organisms which are not target (Rawani et al., 2014). Plant extracts on non-target organisms have also been studied and such insecticides have been claimed safe for non-target organisms (Carvalho et al., 2003; Chowdhury et al., 2009; Adhikari et al., 2012).

Insecticides derived from medicinal plants are called botanical insecticides and they have been screened for their mosquitocidal activities (Elango et al., 2012; Prathibha et al., 2014; Reegan et al., 2015; Bekele and Petros, 2017). Mahanta et al. (2019) reported biological effects caused by Lippia alba essential oils at various stages of $C x$. quinquefasciatus and Aedes aegypti. Pratti et al. (2015) reported the larvicidal activity caused by Schinus terebinthifolia essential oils against Ae. aegypti. Fifty-six substances were identified which constituted the $81.67 \%$ of the essential oil composition. Bekele and Petros (2017) reported repellent activity on Anopheles arabiensis with Brassica nigra; and Aloe pirottae extracts. Jayapriya and Shoba (2015) studied various mosquitocidal activities of different solvent extracts of Rhinacanthus nasutus leaves against $C x$. quinquefasciatus and $A$ e. aegypti. Prajapati et al. (2005) reported that botanical insecticides also have the ability to deter the mosquitoes from egg laying. Active ingredients contained in plant extracts induced physiological and behavioral changes in the gravid female mosquitoes. The active ingredients of plant-based insecticides act as chemosterilent, growth regulators or they may exert olfactory stimuli acting as repellent (Prathibha et al., 2014). Plants that repel insects, also deter oviposition and inhibit adult emergence (Rajkumar and Jebanesan, 2009; Elango et al., 2012; Prathibha et al., 2014).

Chenopodium botrys Linnaeus (Chenopodiaceae) is a medicinal plant known as Skha Kharawa in Dir district of Malakand division, Khyber Pakhtunkhwa, Pakistan. This plant grows near streams in sandy soil and foot hills up to $1,200 \mathrm{~m}$ and its dry leaves decoction is used for the treatment of cough, catarrh, and asthma. The plant is insect repellent and vermifuge for cattle. The parts of $C$. botrys are mixed in soil for killing insect pest larvae (Ilyas, 2015). Plant extracts obtained through non-polar solvent contain more non-polar compounds which can easily penetrate and damage the insect cuticle (Khader, 1999). The aim of the present research was to investigate the oviposition deterrent, larvicidal, pupicidal, adult emergence inhibition and adulticidal activities of non-polar solvent extract of C. botrys whole-plant against $C X$. quinquefasciatus.

\section{Materials and methods}

\subsection{Collection of plant and extract preparation}

The plant $C$. botrys was collected during October 2015 in the foothill near the campus of University of Malakand, Khyber Pakhtunkhwa, Pakistan. The plant was authenticated by plant taxonomist at the Department of Botany, University of Malakand. Chenopodium botrys wholeplants were rinsed in tap water and then dried in shade. The dried plant materials were ground into powder form by electric chopper and then $400 \mathrm{~g}$ powder of $C$. botrys was soaked in $2000 \mathrm{~mL} \mathrm{n}$-hexane in a 3-liter plastic jar for 3 days. Extracts obtained through non-polar solvent contain more non-polar compounds which can easily penetrate and damage insect cuticle, therefore during the present study, n-hexane (a non-polar solvent) was used for preparation of extract. The soaked plant material was filtered through Whatman filter paper no.42. Vacuum rotary evaporator was used for evaporation of solvent. Thick solution of extract from rotary evaporator bulb was poured into $500 \mathrm{~mL}$ glass beaker which was kept open in the laboratory for $24 \mathrm{~h}$ for evaporating the remaining solvent. Brownish extract in paste form was obtained. About $28 \mathrm{~g}$ (14.4\% yield) of $C$. botrys whole-plants n-hexane extract was obtained. The extract was placed at $4^{\circ} \mathrm{C}$ in refrigerator.

\subsection{Column fractionation of n-hexane extract and thin layer chromatography}

The n-hexane extract of the $C$. botrys whole- plant was subjected to fractionation through column chromatography for getting closure to active principles. First of all, a column of glass was aligned vertically. A cotton plug was tamped 
down toward the nozzle of the column. Then the glass column was filled partially with n-hexane. Powder form of silica gel (200 g) was suspended in n-hexane in a $250 \mathrm{~mL}$ glass flask to form its slurry. The slurry was poured over the cotton plug in the glass column to make silica gel bed, a stationary phase. Twenty grams of $C$. botrys extract was dissolved in $100 \mathrm{~mL}$-hexane and then powder form of silica gel was added and stirred. After the extract got dry, the extract was crushed into powder form. The extract powder was then poured into the column (glass) over the bed of silica gel. At the beginning, $100 \%$ non-polar solvent (i.e., n-hexane) was passed as the mobile phase through the column. Then mixture of non-polar and polar solvents in different ratios was passed as the mobile phase. Sufficient volume ( $2 \mathrm{~L}$ ) of each mobile phase was passed through the column. Various fractions of different polarity were collected and dried. Fourteen fractions were obtained which were then subjected to thin layer chromatography (TLC).

During this experiment, small $(5 \times 10 \mathrm{~cm})$ TLC cards of Merck Darmstadt, Germany were cut with the sharp blade. Solutions of fractions were spotted with the help of capillary tubes on the base of TLC cards. Solvent system of $70 \%$ n-hexane and $30 \%$ chloroform was arranged in a glass tank $(14 \times 10 \times 10 \mathrm{~cm})$. TLC cards were then placed in the glass tank for sometimes till the TLC runs up to solvent front slightly lower than top. TLC spots on TLC cards were observed by using ultraviolet UV254, UV365 and visible light. TLC cards were sprayed with ceric sulphate solution and then placed on hot plate for few seconds for increasing visibility. Retention factor (Rf) values were calculated (Equation 1). Fractions with similar Rf values were combined.

$$
\mathrm{Rf}=\frac{\text { Distance from the starting line to the center of spot }}{\text { Distance from starting line to the solvent front }}
$$

The Rf values of all the fourteen fractions were calculated. The fractions with similar Rf value were recombined.

\subsection{Establishment of laboratory colony of $C x$. quinquefasciatus}

Culex quinquefasciatus larvae were collected from the stagnant water bodies at the campus of University of Malakand during May 2016 and reared in the laboratory in $500 \mathrm{~mL}$ plastic containers inside mosquito cage in the laboratory for establishing mosquito colony. Maximum temperature inside the laboratory was $27^{\circ} \mathrm{C}$ to $31^{\circ} \mathrm{C}$. Yeast powder and dog biscuit in 2:3 was supplied as food for the larvae. The larvae developed into pupae from which adults emerged. Adults were initially fed with $10 \%$ sucrose solution in cotton pad. After emergence, mosquito adults were blood fed for eggs development during evening time by restraining mice inside mosquito cage. The use of mice in this study was approved by animal ethical committee at University of Malakand. The gravid female mosquito adults laid eggs in plastic jars containing inside the mosquito cages. The eggs hatched into $1^{\text {st }}$ instar larvae which after few days developed into pupae and adults. All stages of mosquito were available for mosquitocidal experiments.

\subsection{Larvicidal and pupicidal activities}

For conduction of larvicidal bioassay, standard procedures were followed (Larvicides, 2005). During this bioassay, $4000 \mathrm{mg}$ of $C$. botrys whole-plant extract was emulsified in $16 \mathrm{~mL}$ acetone, $5 \mathrm{~mL}$ Tween-80 and some non-chlorinated tap water in $250 \mathrm{~mL}$ glass flask. This emulsified solution was then poured into $2500 \mathrm{~mL}$ plastic bottles to which further water was added till the volume reached to $2000 \mathrm{~mL}$. Thus $2000 \mathrm{~mL}$ extract solution of $2000 \mathrm{ppm}$ extract solution containing $0.8 \%$ acetone and $0.025 \%$ tween 80 was prepared. Then, $100 \mathrm{~mL}$ solutions of $1000,500,250,125,62$ and 30 ppm concentrations were prepared in $200 \mathrm{~mL}$ plastic containers for assessing the larvicidal activity against $2^{\text {nd }}$ and $4^{\text {th }}$ instar larvae of $C x$. quinquefasciatus. Extract solutions of the same concentrations were prepared for assessing the pupicidal activity against $C x$. quinquefasciatus. Control solutions which was consisting of tap water, acetone (0.8\%) and Tween-80 (0.025\%) was also prepared. Second instar larvae ( $n=20$ ) of $C x$. quinquefasciatus were transferred from established colony to each concentration of extract solutions arranged for larvicidal activity against $2^{\text {nd }}$ instar larvae. Twenty $2^{\text {nd }}$ instar larvae were transferred to the control solution jar. Similarly, 20 Cx. quinquefasciatus larvae each of $4^{\text {th }}$ instar were transferred to each concentration of extract solution arranged for larvicidal activity against $4^{\text {th }}$ instar larvae. Twenty $4^{\text {th }}$ instar larvae were transferred to control containers containing non-chlorinated tap water with $0.8 \%$ acetone and $0.025 \%$ Tween- 80 . Twenty pupae of $C x$. quinquefasciatus were transferred to each concentration of extract solutions arranged for pupicidal activity. Twenty pupae were transferred to control solution container. The experiment was conducted in four replicates and percentage mortalities (larvae and pupae) were calculated after $24 \mathrm{~h}$ of exposure period. The criterion for death was lack of response to prodding. The lethal concentration $\left(\mathrm{LC}_{50}\right)$ value of extract was determined.

\subsection{Adulticidal activity}

During the present study, the adulticidal activity of C. botrys whole plant $n$-hexane extract against the adults of female of $C x$. quinquefasciatus was conducted through CDC (centers for disease control and prevention) bottle and filter paper impregnation bioassays. In addition to the adulticidal activity of $C$. botrys whole plant n-hexane extract, the adulticidal activity of six fractions (F1-F6) of the extract was also studied through CDC bottle bioassay. The following are the details:

\subsubsection{CDC bottle bioassay}

During this bioassay, CDC (2010) protocol was followed. Ten milliliter extract solution of $1.25 \%$ was prepared in $25 \mathrm{~mL}$ glass flask. This solution was then sequentially diluted by factor of two into dilutions of $0.625 \%, 0.31 \%$ and $0.15 \%$ concentrations. Four $250 \mathrm{~mL}$ CDC glass bottles were labelled for four concentrations of extract solution (1.25\%, $0.625 \%, 0.31 \%$ and $0.15 \%)$. One milliliter $(1 \mathrm{~mL})$ solution of each concentration was poured into the bottle for respective concentration. The bottles were placed side by side. A control bottle was also placed into which 
$1 \mathrm{~mL}$ of acetone was poured. All the bottles were rotated gently for swirling the solutions and thus the inside of each bottle became coated with the solution. The bottles were rolled continuously after removing their lids for making the inside of bottles dry. Aluminum foil was raped around the bottles to protect them from the effect of light and then placed in horizontal position for $24 \mathrm{~h}$, and subsequently, the solvent evaporated completely. Then, 20 glucose-fed and blood-starved female mosquito adults were introduced into each CDC bottle, including the control bottle with the help of mouth aspirator. The opening of each bottle was closed with their lids after introduction of mosquito adults. The percentage of knock-down of mosquito adults was noted after every $15 \mathrm{~min}$ for $90 \mathrm{~min}$. A mosquito was considered as dead or knocked down if it was unable to move or stand within $60 \mathrm{~min}$ of exposure (WHO, 2016). The median knock-down time $\left(\mathrm{KDT}_{50}\right)$ value of each concentration was determined by subjecting the knockdown data to probit test of Finney (1971). After $90 \mathrm{~min}$, the lid was removed from each bottle and the mouth was covered by fine white cloth mesh. A small cotton pad soaked in $10 \%$ glucose solution was placed on the mesh. Percent mortality was noted after 24 h exposure in CDC bottles (Ajaegbu et al., 2016).

\subsubsection{Paper impregnation bioassay}

During this bioassay, WHO (1981) protocol was followed. Ten milliliter extract solution of $12.5 \mathrm{mg} / \mathrm{mL}$ was prepared in $25 \mathrm{~mL}$ glass flask. This solution was then sequentially diluted by factor of two into dilutions of $6.25 \mathrm{mg} / \mathrm{mL}$, $3.1 \mathrm{mg} / \mathrm{mL}$ and $1.56 \mathrm{mg} / \mathrm{mL}$ concentrations. For four different concentration solutions $(12.5,6.25,3.1$ and $1.5 \mathrm{mg} / \mathrm{mL})$, papers $(12 \times 15 \mathrm{~cm})$ were cut from the sheet of Whatman no.1 filter paper. A control paper of the same size was also cut. From each concentration solution, $2 \mathrm{~mL}$ was applied on the respective filter papers. Thus, four impregnated papers with four extract concentrations of $0.138,0.069,0.034$ and $0.017 \mathrm{mg} / \mathrm{cm}^{2}$, respectively, were prepared. A control $(12 \times 15 \mathrm{~cm})$ paper was also arranged onto which only $2 \mathrm{~mL}$ of acetone was applied. The extract impregnated papers and control papers were placed in exposure tubes in WHO kits for adulticidal activity. Twenty glucose-fed and blood starved female mosquito adults were introduced into each holding tube. The mosquito adults were then exposed to test papers in exposure tubes for 90 min. Percentage of knock-down mosquito adults was noted after every $15 \mathrm{~min}$ for $90 \mathrm{~min}$. The median knock-down time $\left(\mathrm{KDT}_{50}\right)$ value of each concentration was determined by subjecting the knockdown data to probit test of Finney (1971). Mosquitoes were then transferred back to the holding tube and kept for a recovery period of $24 \mathrm{~h}$. A cotton pad soaked in $10 \%$ glucose solution was placed on the mesh screen. After $24 \mathrm{~h}$ of recovery period, mortality of mosquito was recorded.

\subsubsection{Adulticidal activity of column chromatographic fractions}

Six fractions (F1-F6) of C. botrys whole-plants n-hexane extract was tested for adulticidal activity against $C x$. quinquefasciatus female adults though CDC bottle bioassay (Ajaegbu et al., 2016). The concentrations of each fraction tested were $0.2 \%, 0.1 \%, 0.05 \%$ and $0.025 \%$. During this bioassay, mortality of adult mosquitoes was noted for each fraction after $24 \mathrm{~h}$. The detail of CDC bottles coating with extract for the adulticidal activity was the same as described earlier in CDC bottle bioassay.

\subsection{Oviposition deterrent bioassay}

The method of Xue et al. (2001) was followed for oviposition deterrent bioassay. Extract solutions of 31.25, 250 and 1000 ppm showed the lowest, moderate and highest larvicidal activity, therefore these concentrations were selected for conducting oviposition deterrent activity. During this bioassay, stock solution of extract was prepared in tap water by the procedure as practiced for stock solution preparation during larvicidal and pupicidal bioassay. As in larvicidal and pupicidal activity, this solution was also containing $0.05 \%$ of Tween- 80 and $1.6 \%$ of acetone. Three mosquito cages labeled as cage $A$, cage $B$ and cage $C$ were arranged. From the stock solution, three extract solutions of 31.5, 250 and 1000 ppm, $200 \mathrm{~mL}$ each were prepared in three polyethylene containers, $400 \mathrm{~mL}$ each, which were then placed inside cage A, cage $B$ and cage $C$, respectively. The volume of each solution was $200 \mathrm{~mL}$. Inside each cage, $200 \mathrm{~mL}$ tap water having $1.6 \%$ acetone and $0.05 \%$ Tween- 80 was also placed in $400 \mathrm{~mL}$ polyethylene container as control container. The experiment was run in triplicates. Hundred gravid female adults of $C x$. quinquefasciatus were caught from established colonies through mouth aspirator and then introduced into each mosquito cage. After 2 or $3 \mathrm{~d}$ of introduction, egg rafts were observed in the containers. Under dissecting microscope, the total number of egg rafts and eggs were counted for each container. The oviposition deterrence data was presented as \% ER (effective repellence) and mean OAI (oviposition activity indices). According to Govindarajan et al. (2011), negative OAI values represent repellents activity. The \% ER was calculated by applying the Rajkumar and Jebanesan (2009) method (Equation 2).

$$
\% \mathrm{ER}=\frac{\mathrm{NC}-\mathrm{NT}}{\mathrm{NC}} \times 100
$$

In the above formula, NC stands for eggs number in control container, and NT stands for eggs number in extract solution container. The OAI value for each treatment container was calculated by using Kramer and Mulla (1979) method (Equation 3).

$$
\mathrm{QAI}=\frac{\mathrm{NT}-\mathrm{NC}}{\mathrm{NT}+\mathrm{NC}}
$$

In the above formula, Nt stands for total eggs number in extract solution container and Nc stands for the total eggs number in the container labeled as control.

\subsection{Adult emergence inhibition bioassay}

The adult emergence inhibitory activity of extract was studied in the laboratory at 125, 250, 500 and $1000 \mathrm{ppm}$ in the laboratory by following the method of Elimam et al. (2009). During this bioassay, stock solution 
of extract was prepared in tap water by the procedure as practiced for stock solution preparation during larvicidal and pupicidal bioassay. This solution was also containing $0.05 \%$ of Tween- 80 and $1.6 \%$ of acetone. From this stock solution, $300 \mathrm{~mL}$ extract solutions of $125 \mathrm{ppm}, 250 \mathrm{ppm}$, $500 \mathrm{ppm}$ and $1000 \mathrm{ppm}$ were prepared in polyethylene containers, $600 \mathrm{~mL}$ each. Control solution consisting of tap water with acetone $(0.8 \%)$ and Tween-80 $(0.025 \%)$ was also prepared in $600 \mathrm{~mL}$ polyethylene containers and each control container was also placed along each concentration. Then, from the laboratory colony, one hundred $3^{\text {rd }}$ instar $C x$. quinquefasciatus larvae were transferred to each container. This experiment was run in four replicates. Yeast was provided as larval food to each container at two days interval. Each jar was capped with gauze for preventing emerged adult mosquito escape. The jars were checked time to time for noting the pupal and adult appearance. The emerged adults were caught with the help of mouth aspirator and then transferred into reagent bottles, labeled accordingly. Cotton swabs soaked with diethyl ether were applied to the bottles for anaesthetizing the mosquito adults. The timing of this experiment was 14-25 August 2016. Temperature in the laboratory was $30 \pm 4{ }^{\circ} \mathrm{C}$. When no live larva or pupa was left in the control container then the observations were stopped. The number of emerged adults was noted for each container. The effect was expressed as percentage of emergence inhibition (\% EI). The \% EI was calculated by applying the method of Elimam (2007) (Equation 4).

$$
\% \mathrm{EI}=100-\left[\frac{\mathrm{Tx} 100}{\mathrm{C}}\right]
$$

In the above formula, $\mathrm{T}$ stands for the percentage of emerged adults in the container having extract solution and $\mathrm{C}$ stands for the percentage of emerged adults in the container labeled as control. The median emergence inhibition $\left(\mathrm{EI}_{50}\right)$ value of the extract was determined.

\subsection{Analysis of data}

Abbott's formula (Abbott, 1987) was applied for correcting mortality percentages in extract solutions if mortality was observed in control (WHO, 2005). Regression analyses were carried out by subjecting the data to linear regression test. Linear regression equation $\mathrm{Y}=\mathrm{A}+\mathrm{BX}$ was calculated, where ' $Y$ ' represents dependent variable on $Y$ axis, 'A' the Y-intercept, 'B' the slope and ' $\mathrm{X}$ ' represents independent variable on $\mathrm{X}$ axis. To determine the values of $\mathrm{LC}_{50}, \mathrm{KDT}_{50}$ and $\mathrm{EI}_{50}$, the data was subjected to Probit test of Finney (1971). The $\mathrm{LC}_{50}$ values were compared by 95\% confidence limits overlap method of Wheeler et al. (2006). The means of percent mortality were compared by Tukey's test in one-way Anova. Computer software SPSS 16 was used for all these analyses.

\section{Results}

$28 \mathrm{~g}$ (14.4\% yield) extract was obtained from $400 \mathrm{~g}$ powder of $C$. botrys whole-plants. The n-hexane extract was fractionated into several fractions through column chromatography. Fourteen fractions were collected and then subjected to thin layer chromatography (TLC). During TLC, $R f$ values were in the range of $0.2-0.8$. On the basis of similar Rf values, all the 14 fractions were recombined into six fractions (F1-F6) (Table 1).

\subsection{Larvicidal and pupicidal activities}

The $24 \mathrm{~h}$ larvicidal and pupicidal activities of different concentrations ( 31.2 to $1000 \mathrm{ppm}$ ) of C. botrys n-hexane extract against the $2^{\text {nd }}$ and $4^{\text {th }}$ instar larvae and pupae of $C x$. quinquefasciatus mosquito are shown in Table 2.

Table 1. Detail of column chromatographic fractionation of $C$. botrys whole-plant n-hexane extract.

\begin{tabular}{|c|c|c|c|c|}
\hline Mobile phase & Solvents ratio & Rf value & TLC based fractions & Yield (gram) \\
\hline n-Hexane & 100 & 0.2 & $\mathrm{~F} 1$ & $1.3(6.5 \% \mathrm{w} / \mathrm{w})$ \\
\hline n-Hexane: chloroform & $90: 10$ & 0.2 & & \\
\hline n-Hexane: chloroform & $80: 20$ & 0.4 & $\mathrm{~F} 2$ & $1.7(8.5 \% \mathrm{w} / \mathrm{w})$ \\
\hline n-Hexane: chloroform & $70: 30$ & 0.4 & & \\
\hline n-Hexane: chloroform & $60: 40$ & 0.5 & F3 & $2.7(13.5 \% \mathrm{w} / \mathrm{w})$ \\
\hline n-Hexane: chloroform & $50: 50$ & 0.5 & & \\
\hline n-Hexane: chloroform & $60: 40$ & 0.6 & F4 & $3.5(17.4 \% \mathrm{w} / \mathrm{w})$ \\
\hline n-Hexane: chloroform & $30: 70$ & 0.6 & & \\
\hline Chloroform & 100 & 0.7 & F5 & $3.7(18.5 \% \mathrm{w} / \mathrm{w})$ \\
\hline Chloroform: methanol & $80: 20$ & 0.7 & & \\
\hline Chloroform: methanol & $70: 30$ & 0.7 & & \\
\hline Chloroform: methanol & $60: 40$ & 0.8 & F6 & $4.4(22 \% \mathrm{w} / \mathrm{w})$ \\
\hline Chloroform: methanol & $50: 50$ & 0.8 & & \\
\hline Chloroform: methanol & $40: 60$ & 0.8 & & \\
\hline
\end{tabular}


The highest concentration ( $1000 \mathrm{ppm}$ ) of $C$. botrys extract caused $72.4 \pm 6.4 \%, 55.1 \pm 2.9$ and $38.3 \pm 2.1 \%$ mortality of $2^{\text {nd }}$ and $4^{\text {th }}$ instar larvae and pupae, respectively. Lowest concentration (31.2 ppm) of $C$. botrys extract caused $7.4 \pm 1.4 \%$ and $3.8 \pm 1.3 \%$ mortality of $2^{\text {nd }}$ and $4^{\text {th }}$ instar larvae, respectively. This concentration (31.2 ppm) of extract caused no mortality of pupae during $24 \mathrm{~h}$ of exposure. Table 3 shows regression analyses of mean mortality of mosquito larvae and pupae after $24 \mathrm{~h}$ of exposure to extract. There was a strong positive correlation between extract concentration and larval and pupal mortality ( $\mathrm{R}$ square value 0.80 to 0.84 ). Table 3 also shows the probit analyses of mean mortality of mosquito larvae and pupae after $24 \mathrm{~h}$ of exposure to extract. During these analyses, the $24 \mathrm{~h} \mathrm{LC}_{50}$ values of $C$. botrys $\mathrm{n}$-hexane extract against $2^{\text {nd }}$ and $4^{\text {th }}$ instar larvae were $324.6 \mathrm{ppm}$ and $495.6 \mathrm{ppm}$, respectively. The $\mathrm{LC}_{50}$ value of extract against $4^{\text {th }}$ instar larvae was significantly higher than the $\mathrm{LC}_{50}$ value of extract against $2^{\text {nd }}$ instar larvae. The 24 -hour $\mathrm{LC}_{50}$ value of extract against pupae was $950.8 \mathrm{ppm}$ which was significantly $(\mathrm{P}<0.05)$ higher than the $\mathrm{LC}_{50}$ values of this extract against Cx. quinquefasciatus larvae.

\subsection{Adulticidal activity}

Table 4 shows the results of probit analysis of adulticidal activity of $C$. botrys whole-plant n-hexane extract during CDC bottle and filter paper impregnation bioassays. During CDC bottle bioassay, the $\mathrm{KTD}_{50}$ values at the lowest concentration $(0.15 \%)$ and highest concentration (1.25\%) were 413.2 and 123.4 minutes, respectively. The 24-hour mortality during exposure in CDC bottles at $0.15 \%$ and $1.25 \%$ concentrations were $16.7 \pm 3.2$ and $52.4 \pm 2.2 \%$, respectively. During filter paper impregnation bioassay, the $\mathrm{KDT}_{50}$ values of extract at the lowest concentration $\left(0.017 \mathrm{mg} / \mathrm{cm}^{2}\right)$ and highest concentration $\left(0.138 \mathrm{mg} / \mathrm{cm}^{2}\right)$ were 291.1 and 48.6 minutes, respectively. The 24-hour mortality during recovery period at extract concentration $0.017 \mathrm{mg} / \mathrm{cm}^{2}$ and $0.138 \mathrm{mg} / \mathrm{cm}^{2}$ were $25.3 \pm 3.8 \%$ and $81.2 \pm 1.2 \%$, respectively.

\subsubsection{Adulticidal activity of column chromatographic fractions}

The mortality of female $C x$. quinquefasciatus mosquito adults during 24-hour exposure to six column chromatographic fractions (F1-F6) of C. botrys whole-plants

Table 2. Mean mortality of $C x$. quinquefasciatus larvae and pupae after 24 hours of exposure to $C$. botrys extract.

\begin{tabular}{ccccccc}
\hline \multirow{2}{*}{ Stages } & \multicolumn{7}{c}{ Concentration (ppm)/ \% Mortality (Mean \pm SE) } \\
\cline { 2 - 7 } & $\mathbf{1 0 0 0}$ & $\mathbf{5 0 0}$ & $\mathbf{2 5 0}$ & $\mathbf{1 2 5}$ & $\mathbf{6 2 . 5}$ & $\mathbf{3 1 . 2 5}$ \\
\hline $2^{\text {nd }}$ & $72.4 \pm 6.4$ & $58.5 \pm 2.9$ & $33.7 \pm 3.9$ & $22.3 \pm 2.7$ & $8.8 \pm 2.8$ & $7.1 \pm 1.8$ \\
$4^{\text {th }}$ & $55.1 \pm 2.9$ & $52.4 \pm 1.8$ & $28.5 \pm 5.8$ & $17.4 \pm 3.6$ & $8.3 \pm 2.7$ & $2.9 \pm 1.3$ \\
Pupae & $38.3 \pm 2.1$ & $18.3 \pm 2.5$ & $11.7 \pm 2.2$ & $5.2 \pm 1.8$ & $1.3 \pm 1.3$ & 0 \\
\hline
\end{tabular}

Table 3. Regression analyses of $C x$. quinquefasciatus larvae and pupae mean mortality after 24 hours of exposure to $C$. botrys extract.

\begin{tabular}{ccccccccc}
\hline Stages & N & R square & Slope & Intercept & LC50 & L-U & Chi-square & P value \\
\hline 2nd & 24 & 0.84 & 0.069 & 12.6 & 342.6 & $321.3-400.1$ & 18.4 & 0.000 \\
4th & 24 & 0.80 & 0.042 & 6.45 & 495.6 & $461.9-547.3$ & 26.7 & 0.000 \\
Pupae & 24 & 0.84 & 0.037 & -1.206 & 950.8 & $899.4-1047.6$ & 31.8 & 0.000 \\
\hline
\end{tabular}

L-U. = Lower and upper limits of 95\% confidence intervals.

Table 4. Probit analysis of adulticidal activity of $C$. botrys whole-plant n-hexane extract.

\begin{tabular}{|c|c|c|c|c|}
\hline Concentration (\%) & $\mathrm{KDT}_{50}$ & 95\% confidence limits (L-U) & Chi-Square & $\%$ Mortality (Mean \pm SE) \\
\hline \multicolumn{5}{|l|}{ CDC bottle } \\
\hline $1.25 \%$ & 123.4 & $108.6-148.6$ & 18.2 & $52.4 \pm 2.2$ \\
\hline $0.625 \%$ & 171.5 & 154.9- 215.3 & 19.7 & $35.3 \pm 3.7$ \\
\hline $0.31 \%$ & 209.3 & $196.3-233.4$ & 12.8 & $31.8 \pm 3.7$ \\
\hline $0.15 \%$ & 413.2 & 374.4-613.9 & 32.5 & $16.7 \pm 3.2$ \\
\hline \multicolumn{5}{|l|}{ Paper impregnation } \\
\hline $0.138 \mathrm{mg} / \mathrm{cm}^{2}$ & 48.6 & $34.7-63.3$ & 22.1 & $81.2 \pm 1.2$ \\
\hline $0.069 \mathrm{mg} / \mathrm{cm}^{2}$ & 85.7 & 61.6- 121.5 & 16.3 & $68.5 \pm 6.2$ \\
\hline $0.034 \mathrm{mg} / \mathrm{cm}^{2}$ & 129.2 & $95.7-168.9$ & 27.4 & $58.9 \pm 5.1$ \\
\hline $0.017 \mathrm{mg} / \mathrm{cm}^{2}$ & 291.1 & $256.2-348$ & 37.5 & $25.3 \pm 2.3$ \\
\hline
\end{tabular}

L-U. = Lower and upper limits of $95 \%$ confidence intervals. 
Table 5. Results of 24-hour adulticidal activity of column chromatographic fractions of $C$. botrys whole-plant n-hexane extract against Cx. quinquefasciatus.

\begin{tabular}{ccccccc}
\hline \multirow{2}{*}{$\begin{array}{c}\text { Concentration } \\
(\%)\end{array}$} & F1 & F2 & F3 & F4 & F5 & F6 \\
\cline { 2 - 7 } & $50 \pm 9.1$ & $65.0 \pm 8.7$ & $100 \pm 0$ & $67.5 \pm 9.4$ & $52.5 \pm 8.5$ & $30.0 \pm 9.1$ \\
0.2 & $36.3 \pm 5.5$ & $40.0 \pm 10.6$ & $80.0 \pm 4.1$ & $47.5 \pm 9.5$ & $30.0 \pm 9.1$ & $20.0 \pm 5.8$ \\
0.1 & $11.3 \pm 3.1$ & $27.5 \pm 6.6$ & $50.0 \pm 7.4$ & $31.3 \pm 6.6$ & $16.3 \pm 5.5$ & $6.3 \pm 2.3$ \\
0.05 & $1.3 \pm 1.3$ & $5.0 \pm 2.9$ & $30.0 \pm 5.4$ & $17.5 \pm 4.8$ & $6.3 \pm 2.4$ & $1.3 \pm 1.3$ \\
0.025 & 0 & 0 & 0 & 0 & 0 & 0 \\
\hline Control & & & & & & 0 \\
\hline
\end{tabular}

Table 6. Comparison of adulticidal activity of six column chromatographic fractions at highest $(0.2 \%)$ concentration.

\begin{tabular}{ccc}
\hline Fractions & Mortality (\%) & Statistics \\
\hline F1 & $50 \pm 9.1^{\mathrm{b}}$ & \\
F2 & $65.0 \pm 8.7^{\mathrm{c}}$ & DF within groups $=18$ \\
F3 & $100^{\mathrm{d}}$ & \\
F4 & $67.5 \pm 9.4^{\mathrm{c}}$ & $\mathrm{F}=69.9$ \\
F5 & $52.5 \pm 8.5^{\mathrm{b}}$ & $\mathrm{P}=0.00$ \\
F6 & $30.0 \pm 9.1^{\mathrm{a}}$ & \\
\hline
\end{tabular}

Mean values with different letters represent significant difference (at $\mathrm{P}<0.05$ significance level in Tukey's test), alphabetical order is according to increasing mean values.

$\mathrm{n}$-hexane extract is shown in Tables 5 and 6 . The F3 fraction (obtained through mobile phase consisting of n-hexane and chloroform in $60: 40$ or $50: 50 \%$ ratio, $\mathrm{Rf}=0.5$ ) showed significantly higher $(\mathrm{P}<0.05)$ mortality against female mosquito adults when compared to other fractions. Its lowest $(0.02 \%)$ and highest concentration $(0.2 \%)$ concentrations caused $30.0 \pm 5.4 \%$ and $100 \%$ mortality, respectively. The rest of fractions caused lower mortality of female mosquito adults. Lowest mortality was observed for fraction F6 (obtained through mobile phase consisting of chloroform and methanol in 60:40 to 40:60\% ratio, $\mathrm{Rf}=0.8$ ). Its $0.025 \%$ and $0.2 \%$ concentration caused $1.3 \pm 1.3 \%$ and $30.0 \pm 9.1 \%$ mortality, respectively.

\subsection{Oviposition deterrence}

The percentage of effective repellency (\% ER) of plant extract against the adult female gravid mosquito is shown in Table 7. Highest effective repellency (\% ER=71.3 \pm 4.4 ) against the adult female gravid mosquito was noted for the container that was containing $C$. botrys extract solution of highest concentration (1000 ppm). Lowest percentage of effective repellency (\% ER= $37.1 \pm 8.7$ ) was noted for the container that was containing $C$. botrys extract solution of lowest concentration (31.25 ppm). The number of eggs in control and extract solution containers is also shown in Table 7. The range of eggs in control container, lowest extract solution container and highest extract solution container was 715-1399, 411-800 and 209-408, respectively. The oviposition activity indices (OAI) of extract solutions are also shown in Table 7. The solution of highest concentration of extract (1000 ppm) showed lowest mean OAI value $(-0.6 \pm 0.1)$. The solution of lowest concentration of extract (31.25 ppm) showed highest mean OAI value $(0.1 \pm 0)$.

\subsection{Adult emergence inhibition}

The adult emergence inhibition activity of n-hexane extract of $C$. botrys whole plant against $C X$. quinquefasciatus is shown in Table 8 . Maximum percentage ( $\geq 90 \%$ ) of adults emerged from the control containers. Adult emergence was restricted in the extract solution containers. There occurred lowest emergence (17.5 $\pm 11.4 \%$ ) of adults from the containers which were containing extract solution of highest concentration (1000 ppm). There occurred highest emergence $(76.8 \pm 10.2 \%)$ of adults from the containers which were containing extract solution of lowest concentration (125 ppm). The percentage of emergence inhibition (\% EI) of each concentration of extract solution was calculated. The $\%$ EI due to the lowest concentration and highest concentration of extract solution was $18 \pm 11$.7and $82.7 \pm 14.4$, respectively. There was a positive correlation between the concentration of extract solution and \% EI (R square= 0.94). The $\mathrm{EI}_{50}$ value was 312.3ppm.

\section{Discussion}

The control of immature (aquatic) stages of mosquitoes through source reduction, application of insecticides or through combination of both approaches is a preferred strategy for controlling mosquito population (Mulla et al., 2001). Synthetic insecticides are not environment friendly; therefore researchers are now looking for plant-based insecticides to control mosquitoes (Shaalan et al., 2005). The insecticidal potential of $C$. botrys whole- plant n-hexane extract was investigated against $C x$. quinquefasciatus. The $C$. botrys non-polar extract showed remarkable larvicidal and pupicidal activity against $C x$. quinquefasciatus (Table 2). The larvicidal and pupicidal activity of C. botrys whole- plant n-hexane extract was positively correlated with increase in extract concentration. Such correlations have also been reported by other researchers (Adhikari et al., 2012; Rawani et al., 2013). In this research, the extract resulted in higher mortality of $2^{\text {nd }}$ instar larvae $\left(\mathrm{LC}_{50}=324.6 \mathrm{ppm}\right)$ as compared to the mortality of $4^{\text {th }}$ instar 
Table 7. Oviposition deterrent activity of $C$. botrys whole-plant against $C x$. quinquefasciatus.

\begin{tabular}{cccc}
\hline Concentration (ppm) & No. of eggs (range) & \% ER & OAI \\
\hline 1000 (cage 1) & $209-408$ & $71.3 \pm 4.4$ & $0.6 \pm 0.1$ \\
250 (cage 2) & $400-597$ & $56.8 \pm 0.9$ & $0.4 \pm 0.02$ \\
31.2 (cage 3) & $411-800$ & $37.1 \pm 8.7$ & $0.3 \pm 0.1$ \\
Control (cage 4) & $715-1399$ & ----- & - \\
\hline
\end{tabular}

Table 8. Adult emergence inhibition activity of $C$. botrys whole-plant n-hexane extract against $C x$. quinquefasciatus.

\begin{tabular}{crrrrrrr}
\hline $\begin{array}{c}\text { Concentration } \\
(\mathbf{p p m})\end{array}$ & \multicolumn{1}{c}{$\begin{array}{c}\text { \% E in } \\
\text { treatment }\end{array}$} & \multicolumn{1}{c}{$\begin{array}{c}\text { \% E in } \\
\text { control }\end{array}$} & \% EI & R Square & EI $_{\mathbf{5 0}}(\mathbf{p p m})$ & Chi-square & DF \\
\hline 1000 & $17.5 \pm 11.4$ & $94.8 \pm 4.1$ & $82.7 \pm 14.4$ & 0.94 & 312.3 & 0.5 & 2 \\
500 & $38.8 \pm 17.5$ & $95 \pm 4.4$ & $58.5 \pm 20.4$ & & & & \\
250 & $59 \pm 20.4$ & $95.3 \pm 4.1$ & $38.4 \pm 20.5$ & & & & \\
125 & $76.8 \pm 10.2$ & $93.8 \pm 4.3$ & $18 \pm 11.7$ & & & \\
\hline
\end{tabular}

$\% \mathrm{E}=$ percentage of adults emerged, $\mathrm{DF}=$ Degree of Freedom.

larvae $\left(\mathrm{LC}_{50}=495.6 \mathrm{ppm}\right)$. According to de Andrande and Modolo (1991), the higher susceptibility of early instar larvae to the extract solution is due to higher filtration rate in early instars. Chowdhury et al. (2009) and Kovendan et al. (2012) also reported that early instars larvae are more susceptible to insecticidal agents than late instar larvae when exposed. During this study, it was also observed that mosquito pupae are less susceptible to $C$. botrys n-hexane extract than larvae. The extract $\mathrm{LC}_{50}$ value against pupae $\left(\mathrm{LC}_{50}=950.8 \mathrm{ppm}\right)$ was higher than its $\mathrm{LC}_{50}$ values against larvae $\left(\mathrm{LC}_{50}\right.$ against $4^{\text {th }}$ instar larvae $\left.=495.6 \mathrm{ppm}\right)$ (Table 3$)$. Similar trend has also been reported by Panneerselvam et al. (2012). They reported the Artemisia nilagiric LC $_{50}$ values of 311.4, 442.51 and 477.23 ppm against Anopheles stephensi $2^{\text {nd }}$ and $4^{\text {th }}$ instar larvae and pupae, respectively. Pupae possess much thick cuticle therefore they are less sensitive to the insecticidal agents (Beloti et al., 2015).

During the present study, the $C$. botrys whole- plant n-hexane extract also showed adulticidal activity against Cx. quinquefasciatus (Table 4). Panneerselvam et al. (2012) reported the insecticidal potential of Artemisia nilagiric methanol extract against the adults of Anopheles stephensi and Aedes aegypti. Soonwera and Phasomkusolsil (2017)) reported the adulticidal activities of Zanthoxylum limonella fruit essential oil against the adults of $C x$. quinquefasciatus and Ae. aegypti. The insecticidal activities of plant extracts are due to the presence of secondary metabolites. For example, Karabörklü et al. (2011) identified several secondary metabolites in $C$. botrys essential oil in which Veridiflorol, Juniper camphor, Elemol, Caryophyllene oxide, 2-(4a.8-Dimethyl-1, 2, 3, 4, 4a, 5, 6, 7-octahydronaphthalen-2-yl)-prop-2-en-1-ol and $\beta$-Eudesmol were the major metabolites. Harraz et al. (2015) identified twelve metabolites in Chenopodium ambrosioides essential oil in which $\alpha$-terpinene and o-cymene were the major metabolites. Monzote et al. (2014) identified a peroxide known as ascaridole as the major constituent of C. ambrosioides essential oil. Doumbia et al. (2014) identified several secondary metabolites such as limonene, elemol, geraniol, citronellol and citronellal in C. nordus essential oil.

The $C$. botrys whole-plant n-hexane extract was further fractionated through column chromatography into several fractions for getting closure to the active principles. Non-polar and polar solvents in different ratios were passed through the glass column as the mobile phases. Fourteen fractions were collected and then subjected to TLC. On the basis of similar Rf values, all the fractions were recombined into six fractions (F1-F6). The Rf value is a number in the range of 0 - 1 . It is estimated by dividing the distance a compound traveled from the starting point by the distance a solvent traveled from the same starting position. $\mathrm{Rf}$ value characterizes the behavior of compounds in thin layer chromatography (TLC) (Balammal and Kumar, 2014).

Fractions obtained were evaluated for adulticidal activity against $C x$. quinquefasciatus female mosquito adults by applying the CDC bottle bioassay method of Ajaegbu et al. (2016) (Tables 5 and 6). The fraction F3 (obtained through mobile phase consisting of 60:40 to 50:50\% n-hexane and chloroform, $\mathrm{Rf}=0.5$ ) showed strongest adulticidal activity. Its $0.02 \%$ concentration caused $30.0 \pm 5.4 \%$ mortality and its $0.2 \%$ concentration caused $100 \%$ mortality of female adults of $C X$. quinquefasciatus. The strongest adulticidal activity of fraction F3 shows that it contains strong insecticidal compounds. These findings can provide a basis for the isolation of insect repellent and insecticidal compounds of plant origin. Kramer et al. (2008) also performed such insecticidal activity-oriented fractionation of Spondias mombin leaf methanol extract and its fractions against Aedes aegypti. The most effective fraction (dichloromethane fraction) was further fractionated and the active principles were identified. Sharma et al. (2014) also performed insecticidal activity-oriented fractionation of Artemisia annua leaf chloroform extract against Anopheles stephensi.

The n-hexane extract of $C$. botrys whole-plant is also oviposition deterrent against mosquitoes. The gravid female adults of $C x$. quinquefasciatus mosquito were mostly avoiding 
the containers for egg laying which were containing $C$. botrys whole-plant n-hexane extract solution (Table 7). Highest concentration of extract solution showed maximum oviposition deterrence. The deterrence of oviposition was presented in percent effective repellence (\% ER) and oviposition activity index (OAI). Highest $\%$ ER was $71.3 \pm 4.4$, which was noted for the container containing $1000 \mathrm{ppm}$ of C. botrys whole-plant n-hexane extract solution. Negative OAI values were noted for the containers containing extract solution. According to Govindarajan et al. (2011), negative OAIs values indicate oviposition deterrence. Few studies have been conducted on the oviposition deterrent activity of medicinal plants against mosquitoes (Elimam et al., 2009; Kamaraj et al., 2009; Prathibha et al., 2014; Reegan et al., 2015). The alterations induced in the behavior and physiology of the adult female gravid mosquitoes by the plant extracts may be the main reason of oviposition deterrence (Raghavendra et al., 2014). Some active principles contained in plant extracts act as chemosterilent or growth regulators while some create olfactory stimuli that cause repellence (Prathibha et al., 2014). Most of the insect repellent plants are oviposition deterrent (Mehra and Hiradhar, 2002; Rajkumar and Jebanesan, 2009).

The adult emergence inhibition activity of $C$. botrys whole-plant n-hexane extract was also studied during the present research (Table 8 ). This was expressed in percentage of emergence inhibition (\% EI). The extract solutions in the containers restricted the emergence of adults. The $\mathrm{EI}_{50}$ value of $C$. botrys whole-plant n-hexane extract was $312.3 \mathrm{ppm}$. Medicinal plants contain active principles which may be responsible for inhibition of adult emergence (Arivoli and Tennyson, 2011). They may inhibit the development of mosquito immature stages (Arivoli and Tennyson, 2011). According to Shaalan et al. (2005), plant extracts have the potential to inhibit moulting, delay development of larval stages, increase pupal duration, cause melanization processes, mortality and structural abnormalities during moulting. Few studies have been conducted on the adult emergence inhibition activity of medicinal plants against mosquitoes (Wiesman and Chapagain, 2006; Howard et al., 2009; Arivoli and Tennyson, 2011; Elango, Rahuman et al., 2012).

\section{Conclusion}

The n-hexane extract of $C$. botrys whole- plant possesses strong larvicidal, adulticidal, oviposition deterrent and adult emergence inhibitory activities against $C x$. quinquefasciatus. Its fractions obtained after elution of non-polar and polar solvents in different ratio through silica gel column show strong adulticidal activity against female $C x$. quinquefasciatus even at very low concentrations. Hence, these fractions could be effective insecticides against $C x$. quinquefasciatus, the most common and abundant nuisance mosquito species.

\section{Acknowledgements}

The authors are thankful to Mr. Mirza Gul for his help in plant collection from foothill areas, and Mr. Afzal Hussain for his help in larval collection from cemented drains near the campus of University of Malakand.

\section{References}

ABBOTT, W., 1987. A method of computing the effectiveness of an insecticide. Journal of the American Mosquito Control Association, vol. 3, no. 2, pp. 302-303. PMid:3333059.

ADHIKARI, U., SINGHA, S. and CHANDRA, G., 2012. In vitro repellent and larvicidal efficacy of Swietenia mahagoni against the larval forms of Culex quinquefasciatus Say. Asian Pacific Journal of Tropical Biomedicine, vol. 2, no. 1, pp. S260-S264. http://dx.doi. org/10.1016/S2221-1691(12)60171-3.

AJAEGBU, E.E., DANGA, S.P.Y., CHIJOKE, I.U. and OKOYE, F.B.C., 2016. Mosquito adulticidal activity of the leaf extracts of Spondias mombin L. against Aedes aegypti L. and isolation of active principles. Journal of Vector Borne Diseases, vol. 53, no. 1, pp. 17-22.

ANDRANDE, C.F.S.D. and MODOLO, M., 1991. Susceptibility of Aedes aegypti larvae to temephos and Bacillus thuringiensis var israelensis in integrated control. Revista de Saude Publica, vol. 25, no. 3, pp. 184-187. http://dx.doi.org/10.1590/S003489101991000300004. PMid:1726480.

ANDREADIS, T.G., 2012. The contribution of Culex pipiens complex mosquitoes to transmission and persistence of West Nile virus in North America. Journal of the American Mosquito Control Association, vol. 28, no. 4, pp. 137-151. http://dx.doi. org/10.2987/8756-971X-28.4s.137.

ARIVOLI, S. and TENNYSON, S., 2011. Larvicidal and adult emergence inhibition activity of Abutilon indicum (Linn.) (Malvaceae) leaf extracts against vector mosquitoes (Diptera: culicidae). Journal of Biopesticides, vol. 4, no. 1, pp. 27.

BALAMMAL, G. and KUMAR, S., 2014. A review on basic chromatographic techniques. Indian Journal of Pharmaceutical Science \& Research, vol. 4, no. 4, pp. 221-238.

BEG, M., NAQVI, A., ZAMAN, V. and HUSSAIN, R., 2001. Tropical pulmonary eosinophilia and filariasis in Pakistan. The Southeast Asian Journal of Tropical Medicine and Public Health, vol. 32, no. 1, pp. 73-75. PMid:11485099.

BEKELE, D. and PETROS, B., 2017. Repellent effects of Aloe pirottae (Aloaceae) gel extract and Brassica nigra (Brassicaceae) essential oil against the malaria vector, Anopheles arabiensis Patton (Diptera: culicidae). Biochemistry and Analytical Biochemistry, vol. 6, no. 336, pp. 2161.

BELOTI, V.H., ALVES, G.R., ARAÚJO, D.F.D., PICOLI, M.M., MORAL, R.A., DEMÉTRIO, C.G. and YAMAMOTO, P.T., 2015. Lethal and sublethal effects of insecticides used on citrus, on the ectoparasitoid Tamarixia radiata. PLoS One, vol. 10, no. 7, pp. e0132128. http:// dx.doi.org/10.1371/journal.pone.0132128. PMid:26132327.

BENELLI, G., 2015. Plant-borne ovicides in the fight against mosquito vectors of medical and veterinary importance: a systematic review. Parasitology Research, vol. 114, no. 9, pp. 3201-3212. http://dx.doi.org/10.1007/s00436-015-4656-z. PMid:26239801.

CARVALHO, A.F.U., MELO, V.M.M., CRAVEIRO, A.A., MACHADO, M.I.L., BANTIM, M.B. and RABELO, E.F., 2003. Larvicidal activity of the essential oil from Lippia sidoides Cham. against Aedes aegypti Linn. Memorias do Instituto Oswaldo Cruz, vol. 98, no. 4, pp. 569-571. http://dx.doi.org/10.1590/S0074-02762003000400027. PMid:12937776.

CASIDA, J.E. and DURKIN, K.A., 2013. Neuroactive insecticides: targets, selectivity, resistance, and secondary effects. Annual 
Review of Entomology, vol. 58, no. 1, pp. 99-117. http://dx.doi. org/10.1146/annurev-ento-120811-153645. PMid:23317040.

CENTERS FOR DISEASE CONTROL AND PREVENTION - CDC, 2010 [viewed 11 July 2020]. Guideline for evaluating insecticide resistance in vectors using the $C D C$ bottle bioassay [online]. 1st ed. Atlanta: CDC. Available from: http://www.cdc.gov/malaria

CHOWDHURY, N., CHATTERJEE, S.K., LASKAR, S. and CHANDRA, G., 2009. Larvicidal activity of Solanum villosum Mill (Solanaceae: Solanales) leaves to Anopheles subpictus Grassi (Diptera: Culicidae) with effect on non-target Chironomus circumdatus Kieffer (Diptera: Chironomidae). Journal of Pest Science, vol. 82, no. 1, pp. 13-18. http://dx.doi.org/10.1007/s10340-008-0213-1.

DAS, B.P., DEOBHANKAR, K., POHEKAR, K.N., MARATHE, R., HUSAIN, S.A. and JAMBULINGAM, P., 2016. Laboratory bioassay of Chilodonella uncinata, an entomopathogenic protozoan, against mosquito larvae. Journal of Mosquito Research, vol. 6, no. 10, pp. 1-10. http://dx.doi.org/10.5376/jmr.2016.06.0010.

DOUMBIA, M., YOBOUE, K., KOUAMÉ, L.K., COFFI, K., KRA, D.K., KWADJO, K.E., DOUAN, B.G. and DAGNOGO, M., 2014. Toxicity of Cymbopogon nardus (Glumales: Poacea) against four stored food products insect pests. International Journal of Farming and Allied Sciences, vol. 3, no. 8, pp. 903-909.

ELANGO, G., RAHUMAN, A.A., KAMARAJ, C., BAGAVAN, A. and ZAHIR, A.A., 2012. Adult emergence inhibition and adulticidal activity of leaf crude extracts against Japanese encephalitis vector, Culex tritaeniorhynchus. Journal of King Saud University-Science, vol. 24 no. 1, pp. 73-80. http://dx.doi.org/10.1016/j.jksus.2010.08.012.

ELIMAM, A., 2007. Larvicidal, ovicidal, oviposition deterrence and emergence inhibition activity of selected Sudanese plants against Anopheles arabiensis and Culex quinquefasciatus. Khartoum: Department of Biology, Faculty of Education University of Khartoum. PhD in Philosophy in Biology.

ELIMAM, A.M., ELMALIK, K.H. and ALI, F.S., 2009. Larvicidal, adult emergence inhibition and oviposition deterrent effects of foliage extract from Ricinus communis L. against Anopheles arabiensis and Culex quinquefasciatus in Sudan. Tropical Biomedicine, vol. 26, no. 2, pp. 130-139. PMid:19901899.

FARAJOLLAHI, A., FONSECA, D.M., KRAMER, L.D. and KILPATRICK, A.M., 2011. Bird biting mosquitoes and human disease: A review of the role of Culex pipiens complex mosquitoes in epidemiology. Infection, Genetics and Evolution, vol. 11, no. 7, pp. 1577-1585. http://dx.doi.org/10.1016/j.meegid.2011.08.013. PMid:21875691.

FINNEY, D.J., 1971. Probit analysis. Cambridge, UK: Cambridge University Press.

GHOSH, A., CHOWDHURY, N. and CHANDRA, G., 2012. Plant extracts as potential mosquito larvicides. The Indian Journal of Medical Research, vol. 135, no. 5, pp. 581-598. PMid:22771587.

GLAD, A. and CRAMPTON, L.H., 2015. Local prevalence and transmission of avian malaria in the Alakai Plateau of Kauai, Hawaii, U.S.A. Journal of Vector Ecology, vol. 40, no. 2, pp. 221229. http://dx.doi.org/10.1111/jvec.12157. PMid:26611954.

GOVINDARAJAN, M., MATHIVANAN, T., ELUMALAI, K., KRISHNAPPA, K. and ANANDAN, A., 2011. Ovicidal and repellent activities of botanical extracts against Culex quinquefasciatus, Aedes aegypti and Anopheles stephensi (Diptera: culicidae). Asian Pacific Journal of Tropical Biomedicine, vol. 1, no. 1, pp. 43-48. http:// dx.doi.org/10.1016/S2221-1691(11)60066-X. PMid:23569723.

GULLAN, P.J. and CRANSTON, P.S., 2014. The insects: an outline of entomology. John Wiley \& Sons.

HARRAZ, F.M., HAMMODA, H.M., EL GHAZOULY, M.G., FARAG, M.A., EL-ASWAD, A.F. and BASSAM, S.M., 2015. Chemical composition, antimicrobial and insecticidal activities of the essential oils of Conyza linifolia and Chenopodium ambrosioides. Natural Product
Research, vol. 29, no. 9, pp. 879-882. http://dx.doi.org/10.1080 |14786419.2014.988714. PMid:25495783.

HOWARD, A.F., ADONGO, E.A., HASSANALI, A., OMLIN, F.X., WANJOYA, A., ZHOU, G. and VULULE, J., 2009. Laboratory Evaluation of the aqueous extract of Azadirachta indica (Neem) wood chippings on Anopheles gambiae s.s. (Diptera: Culicidae) Mosquitoes. Journal of Medical Entomology, vol. 46, no. 1, pp. 107-114. http://dx.doi. org/10.1603/033.046.0114. PMid:19198524.

ILAHI, I. and SULEMAN, M., 2013. Species composition and relative abundance of mosquitoes in Swat, Pakistan. Intrnational Journal of Innovative Applied Studies, vol. 2, no. 4, pp. 4542463.

ILYAS, M., 2015. Phytosociological and ethnobotanical appraisal of kabal valley swat with especial reference to plant biodiversity conservation. Pakistan: Pir Mahar Ali Sha Arid Agriculture University Rawalpindi.

JAYAPRIYA, G. and SHOBA, G., 2015. Adulticidal and repellent activities of Rhinacanthus nasutus leaf extracts against Aedes aegypti Linn and Culex quinquefasciatus Say. Journal of Entomology and Zoology Studies, vol. 3, no. 1, pp. 154-159.

KAMARAJ, C., BAGAVAN, A., RAHUMAN, A.A., ZAHIR, A.A., ELANGO, G. and PANDIYAN, G., 2009. Larvicidal potential of medicinal plant extracts against Anopheles subpictus Grassi and Culex tritaeniorhynchus Giles (Diptera: culicidae). Parasitology Research, vol. 104, no. 5, pp. 1163-1171. http://dx.doi.org/10.1007/s00436008-1306-8. PMid:19085005.

KARABÖRKLÜ, S., AYVAZ, A., YILMAZ, S. and AKBULUT, M., 2011. Chemical composition and fumigant toxicity of some essential oils against Ephestia kuehniella. Journal of Economic Entomology, vol. 104, no. 4, pp. 1212-1219. http://dx.doi.org/10.1603/EC10284. PMid:21882685.

KHADER, K.M.A., 1999. Investigations on ecofriendly natural insecticides. Kerala: School of Environmental Studies, Cochin University of Science and Technology Kochi, 25 p. PhD Thesis in Philosophy.

KOVENDAN, K., MURUGAN, K., VINCENT, S. and BARNARD, D.R., 2012. Studies on larvicidal and pupicidal activity of Leucas aspera Willd. (Lamiaceae) and bacterial insecticide, Bacillus sphaericus, against malarial vector, Anopheles stephensi Liston. (Diptera: Culicidae). Parasitology Research, vol. 110, no. 1, pp. 195-203. http://dx.doi.org/10.1007/s00436-011-2469-2. PMid:21626422.

KRAMER, L., STYER, L.M. and EBEL, G.D., 2008. A global perspective on the epidemiology of West Nile virus. Annual Review of Entomology, vol.53, no. 1, pp.61-81. http://dx.doi.org/10.1146/ annurev.ento.53.103106.093258. PMid:17645411.

KRAMER, W.L. and MULLA, M.S., 1979. Oviposition attractants and repellents of mosquitoes: oviposition responses of Culex mosquitoes to organic infusions. Environmental Entomology, vol. 8, no. 6, pp. 1111-1117. http://dx.doi.org/10.1093/ee/8.6.1111.

LARVICIDES, M., 2005. Guidelines for laboratory and field testing of mosquito larvicides. Geneva: WHO.

LEE, S.E., KIM, J.E. and LEE, H.S., 2001. Insecticide resistance in increasing interest. Journal of Applied Biological Chemistry, vol. 44, no. 3, pp. 105-112.

MAHANTA, S., SARMA, R. and KHANIKOR, B., 2019. The essential oil of Lippia alba Mill (Lamiales: Verbenaceae) as mosquitocidal and repellent agent against Culex quinquefasciatus Say (Diptera: Culicidae) and Aedes aegypti Linn (Diptera: Culicidae). Journal of Basic \& Applied Zoology, vol. 80, no. 1, pp. 64. http://dx.doi. org/10.1186/s41936-019-0132-0.

MANDAL, S., GHOSH, A., BHATTACHARJEE, I. and CHANDRA, G., 2008. Biocontrol efficiency of odonate nymphs against larvae of the mosquito, Culex quinquefasciatus Say, 1823. Acta 
Tropica, vol. 106, no. 2, pp. 109-114. http://dx.doi.org/10.1016/j. actatropica.2008.02.002. PMid:18378207.

MEHRA, B. and HIRADHAR, P., 2002. Cuscuta hyalina Roth., an insect development inhibitor against common house mosquito Culex quinquefasciatus Say. Journal of Environmental Biology, vol. 23, no. 3, pp. 335-339. PMid:12597579.

MONZOTE, L., PASTOR, J., SCULL, R. and GILLE, L., 2014. Antileishmanial activity of essential oil from Chenopodium ambrosioides and its main components against experimental cutaneous leishmaniasis in BALB/c mice. Phytomedicine, vol. 21, no. 8-9, pp. 1048-1052. http://dx.doi.org/10.1016/j. phymed.2014.03.002. PMid:24768411.

MULLA, S., THAVARA, U., TAWATSIN, A., KONG-NGAMSUK, W., CHOMPOOSRI, J. and SU, T., 2001. Mosquito larval control with Bacillus sphaericus: reduction in adult population in low-income communities in Nonthaburi Province, Thailand. Journal of Vector Ecology, vol. 26, no. 2, pp. 221-231. PMid:11813660.

PANNEERSELVAM, C., MURUGAN, K., KOVENDAN, K. and MAHESH KUMAR, P., 2012. Mosquito larvicidal, pupicidal, adulticidal, and repellent activity of Artemisia nilagirica (Family: Compositae) against Anopheles stephensi and Aedes aegypti. Parasitology Research, vol. 111, no. 6, pp. 2241-2251. http://dx.doi.org/10.1007/ s00436-012-3073-9. PMid:22903417.

PRAJAPATI, V., TRIPATHI, A., AGGARWAL, K. and KHANUJA, S., 2005. Insecticidal, repellent and oviposition-deterrent activity of selected essential oils against Anopheles stephensi, Aedes aegypti and Culex quinquefasciatus. Bioresource Technology, vol. 96, no. 16, pp. 1749-1757. http://dx.doi.org/10.1016/j. biortech.2005.01.007. PMid:16051081.

PRATHIBHA, K., RAGHAVENDRA, B. and VIJAYAN, V., 2014. Larvicidal, ovicidal, and oviposition-deterrent activities of four plant extracts against three mosquito species. Environmental Science and Pollution Research International, vol. 21, no. 10, pp. 6736-6743. http://dx.doi.org/10.1007/s11356-014-2591-7. PMid:24562451.

PRATTI, D.L., RAMOS, A.C., SCHERER, R., CRUZ, Z.M. and SILVA, A.G., 2015. Mechanistic basis for morphological damage induced by essential oil from Brazilian pepper tree, Schinus terebinthifolia, on larvae of Stegomyia aegypti, the dengue vector. Parasites \& Vectors, vol. 8, no. 1, pp. 136. http://dx.doi.org/10.1186/s13071015-0746-0. PMid:25886180.

RAJKUMAR, S. and JEBANESAN, A., 2009. Larvicidal and oviposition activity of Cassia obtusifolia Linn (Family: Leguminosae) leaf extract against malarial vector, Anopheles stephensi Liston (Diptera: Culicidae). Parasitology Research, vol. 104, no. 2, pp. 337-340. http://dx.doi.org/10.1007/s00436-008-1197-8. PMid:18818950.

RAMAIAH, K.D., DAS, P.K., VANAMAIL, P. and PANI, S.P., 2003. The impact of six rounds of single-dose mass administration of diethylcarbamazine or ivermectin on the transmission of Wuchereria bancrofti by Culex quinquefasciatus and its implications for lymphatic filariasis elimination programmes. Tropical Medicine E International Health, vol. 8, no. 12, pp. 1082-1092. http:// dx.doi.org/10.1046/j.1360-2276.2003.01138.x. PMid:14641843.

RAWANI, A., CHOWDHURY, N., GHOSH, A., LASKAR, S. and CHANDRA, G., 2013. Mosquito larvicidal activity of Solanum nigrum berry extracts. The Indian Journal of Medical Research, vol. 137, no. 5 , pp. 972-976. PMid:23760385.
RAWANI, A., GHOSH, A. and CHANDRA, G., 2014. Laboratory evaluation of molluscicidal \& mosquito larvicidal activities of leaves of Solanum nigrum L. The Indian Journal of Medical Research, vol. 140, no. 2, pp. 285-295. PMid:25297363.

REEGAN, A.D., GANDHI, M.R., PAULRAJ, M.G. and IGNACIMUTHU, S., 2015. Ovicidal and oviposition deterrent activities of medicinal plant extracts against Aedes aegypti L. and Culex quinquefasciatus Say mosquitoes (Diptera: Culicidae). Osong Public Health and Research Perspectives, vol. 6, no. 1, pp. 64-69. http://dx.doi. org/10.1016/j.phrp.2014.08.009. PMid:25737834.

SHAALAN, E.A.S., CANYON, D., YOUNES, M.W., ABDEL-WAHAB, H. and MANSOUR, A.H., 2005. A review of botanical phytochemicals with mosquitocidal potential. Environment International, vol. 31, no. 8, pp. 1149-1166. http://dx.doi.org/10.1016/j. envint.2005.03.003. PMid:15964629.

SHARMA, G., KAPOOR, H., CHOPRA, M., KUMAR, K. and AGRAWAL, V., 2014. Strong larvicidal potential of Artemisia annua leaf extract against malaria (Anopheles stephensi Liston) and dengue (Aedes aegypti L.) vectors and bioassay-driven isolation of the marker compounds. Parasitology Research, vol. 113, no. 1, pp. 197-209. http://dx.doi.org/10.1007/s00436-013-3644-4. PMid:24158647.

SIMONSEN, P.E., 2009. Filariases. In: GC Cook and AI Zumla, editors. Manson's tropical diseases. 22nd ed. London: Saunders Elsevier, pp. 1477-1513.

SOONWERA, M. and PHASOMKUSOLSIL, S., 2017. Adulticidal, larvicidal, pupicidal and oviposition deterrent activities of essential oil from Zanthoxylum limonella Alston (Rutaceae) against Aedes aegypti (L.) and Culex quinquefasciatus (Say). Asian Pacific Journal of Tropical Biomedicine, vol. 7, no. 11, pp. 967-978. http://dx.doi.org/10.1016/j.apjtb.2017.09.019.

WHEELER, M.W., PARK, R.M. and BAILER, A.J., 2006. Comparing median lethal concentration values using confidence interval overlap or ratio tests. Environmental Toxicology and Chemistry, vol. 25, no. 5, pp. 1441-1444. http://dx.doi.org/10.1897/05320R.1. PMid:16704080.

WIESMAN, Z. and CHAPAGAIN, B.P., 2006. Larvicidal activity of saponin containing extracts and fractions of fruit mesocarp of Balanites aegyptiaca. Fitoterapia, vol. 77, no. 6, pp. 420-424. http://dx.doi.org/10.1016/j.fitote.2006.05.012. PMid:16814957.

WORLD HEALTH ORGANIZATION - WHO, 1981. WHO/VBC/81.80: instructions for determining the susceptibility or resistance of adult mosquitoes to organochlorine, organophosphate and carbamate insecticides: diagnostic test. Geneva: WHO.

WORLD HEALTH ORGANIZATION - WHO, 2005. Guidelines for laboratory and field testing of mosquito larvicides. Geneva: WHO Communicable Disease Control, Prevention and Eradication / WHO Pesticide Evaluation Scheme.

WORLD HEALTH ORGANIZATION - WHO., 2016. WHO/ZIKV/VC/16.1: monitoring and managing insecticide resistance in aedes mosquito populations: interim guidance for entomologist. Geneva: WHO.

XUE, R.D., BARNARD, D. and ALI, A., 2001. Laboratory and field evaluation of insect repellents as oviposition deterrents against the mosquito Aedes albopictus. Medical and Veterinary Entomology, vol. 15, no. 2, pp. 126-131. http://dx.doi.org/10.1046/ j.0269-283x.2001.00301.x. PMid:11434545. 